\title{
Prognostic value of c-Met overexpression in pancreatic adenocarcinoma: a meta-analysis
}

\author{
Jung Han Kim ${ }^{1}$, Hyeong Su Kim ${ }^{1}$, Bum Jun Kimr, ${ }^{1,2}$ Jin Lee $^{3}$ and Hyun Joo Jang ${ }^{3}$ \\ ${ }^{1}$ Division of Hemato-Oncology, Department of Internal Medicine, Kangnam Sacred-Heart Hospital, Hallym University Medical \\ Center, Hallym University College of Medicine, Seoul 07441, Republic of Korea \\ ${ }^{2}$ Department of Internal Medicine, National Army Capital Hospital, The Armed Forces Medical Command, Sungnam 13574, \\ Republic of Korea \\ ${ }^{3}$ Division of Gastroenterology, Department of Internal Medicine, Dongtan Sacred-Heart Hospital, Hallym University Medical \\ Center, Hallym University College of Medicine, Hwasung 18450, Republic of Korea
}

Correspondence to: Jung Han Kim, email: harricil@hotmail.com Hyun Joo Jang, email: jhj1229@hallym.or.kr

Keywords: c-Met, pancreatic cancer, prognostic value, meta-analysis

Received: June 01, 2017

Accepted: August 07, 2017

Published: August 22, 2017

Copyright: Kim et al. This is an open-access article distributed under the terms of the Creative Commons Attribution License 3.0 (CC BY 3.0), which permits unrestricted use, distribution, and reproduction in any medium, provided the original author and source are credited.

\begin{abstract}
The overexpression of c-Met protein has been detected in pancreatic adenocarcinoma (PAC). However, its prognostic impact remains unclear. We performed this meta-analysis to evaluate the prognostic value of c-Met overexpression in PAC. A systematic computerized search of the electronic databases such as PubMed, Embase, and Google Scholar was carried out. From 5 studies, 423 patients who underwent surgical resection for PAC were included in the meta-analysis. Compared with patients with PAC showing low c-Met expression, patients with c-Met-high tumor had significantly worse disease-free survival (hazard ratio $=1.94[95 \%$ confidence interval, 1.46-2.56], $P=0.00001$ ) and overall survival (hazard ratio $=1.86[95 \%$ confidence interval, 1.19-2.91], $P=0.006$ ). In conclusion, this meta-analysis demonstrates that c-Met overexpression is a significant prognostic marker for poor survival in patients who underwent surgical resection for PAC.
\end{abstract}

\section{INTRODUCTION}

Despite the recent advances in diagnostic and therapeutic modalities, pancreatic adenocarcninoma (PAC) is still among lethal malignancies with 5-year survival rates of less than $10 \%[1,2]$. Surgical resection with or without adjuvant therapy is the potential curative therapy for patients with a localized disease, but patients usually present with unresectable advanced diseases at the time of diagnosis. Moreover, most patients who underwent complete resection develop recurrent diseases during the course of their disease [3, 4]. For advanced or metastatic PAC, systemic chemotherapy can prolong survival compared with best supportive care, but unfortunately median overall survival (OS) was less than ten months $[5,6]$. Thus, the development of more effective treatment is mandated.

With more understanding of molecular mechanisms of carcinogenesis, novel molecular agents targeting epidermal growth factor receptor, vascular epithelial growth factor receptor, or c-Met has been proposed for the treatment of PAC [7, 8]. However, the identification of biomarkers associated with response is essential to improve therapeutic outcomes of these molecular agents. Therefore, it is still necessary to accumulate our knowledge at the genomic and molecular levels.

$M E T$ is a proto-oncogene that encodes tyrosine kinase receptor for hepatocyte growth factor (HGF) [9]. HGF, also known as a scatter factor, binds to c-Met protein (the product of $M E T$ gene) and initiates autophosphorylation of an intracellular kinase on the betasubunit of the receptor. This interaction allows the binding and activation of multiple signaling molecules such as Src, PI3K, Gab1, SOS, or MEK1/2 [9, 10]. This muti-faceted activation results in cellular alterations that contribute to carcinogenesis. The HGF-c-Met signaling pathway ultimately leads to tumor differentiation and proliferation, cellular invasion, angiogenesis and 
metastasis $[11,12]$. The enhanced expression of c-Met protein has been observed in various tumors such as breast cancer [13], lung cancer [14], gastric cancer [15], colorectal cancer [16], cervix cancer [17], or hepatocellular carcinoma [18]. Several meta-analyses demonstrated that c-Met was a strong prognostic indicator of poor survival [13-17].

The overexpression of c-Met protein has also been detected in PAC [19-25]. However, most studies had a small number of patients, and its prognostic role remains unclear. We performed this meta-analysis to evaluate the prognostic value of c-Met overexpression in PAC.

\section{RESULTS}

\section{Results of search}

Figure 1 shows the flowchart of our study. A total of 158 potentially relevant studies were initially found, but 151 of them were excluded after screening the titles and abstracts. Of the remaining 7 potentially eligible studies, 2 were further excluded by the inclusion criteria because the required hazard ratio (HR) with $95 \%$ confidence interval (CI) stratified by c-Met expression were not extractable from the presented data $[19,20]$. Finally, 5 studies were included in the meta-analysis [21-25].

\section{Characteristics of the included studies}

Table 1 summarizes the main characteristics and clinical outcomes of the five included studies. All the studies were performed retrospectively in patients with PAC who underwent radical resection. From the 5 studies, 423 patients were included in the meta-analysis. In one study with 92 patients [25], $56(60.8 \%)$ received preoperative chemoradiotherapy. Except for two studies $[21,22]$, three provided the data of adjuvant treatment. Out of 311 patients from the 3 studies [23-25], 214 (68.8\%) received adjuvant chemotherapy with or without radiation.

\section{c-Met expression assignation}

c-Met expression was assessed by immunohistochemistry (IHC). There was a marked heterogeneity between the thresholds used to dichotomize c-Met status (c-Met ${ }^{\text {low }}$ or c-Met ${ }^{\text {high }}$ ). IHC criteria were briefly summarized in the Table 1 . The rate of high c-Met expression ranged from $27.5 \%$ [24] to $60.6 \%$ [22].

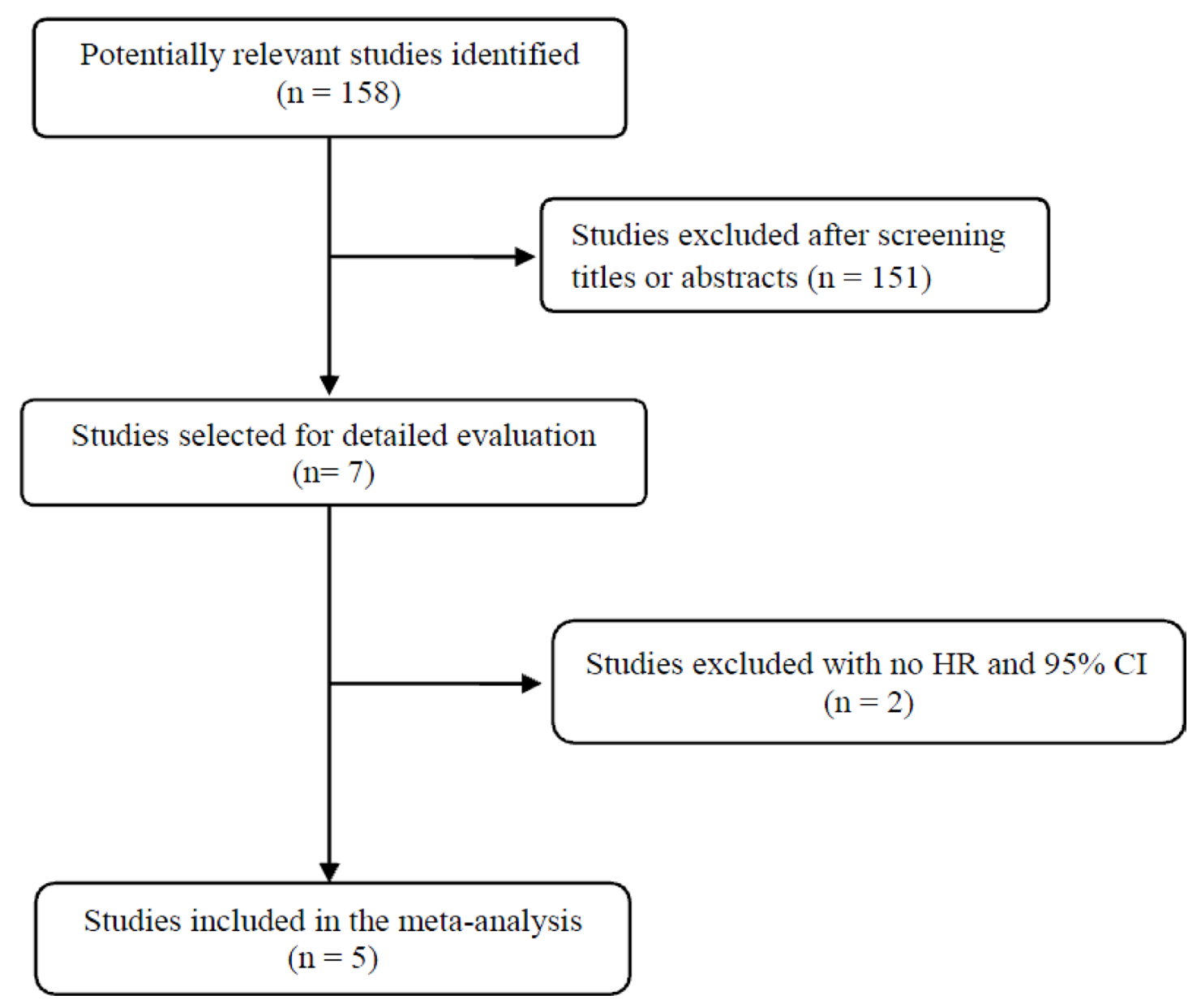

Figure 1: Flow diagram of search process. 
Table 1: Summary of the five included studies

\begin{tabular}{|c|c|c|c|c|c|c|c|c|c|}
\hline \multirow[b]{2}{*}{$\begin{array}{l}\text { Author (year) } \\
\text { Location }\end{array}$} & \multirow[b]{2}{*}{$\begin{array}{l}\text { Antibody, } \\
\text { dilution }\end{array}$} & \multirow[b]{2}{*}{$\begin{array}{l}\text { No. of } \\
\text { patients }\end{array}$} & \multirow[b]{2}{*}{ IHC criteria } & \multicolumn{2}{|c|}{ c-Met results } & \multirow[b]{2}{*}{$\begin{array}{l}\text { mDFS (mo) } \\
\text { Low v high }\end{array}$} & \multirow[b]{2}{*}{$\begin{array}{l}\text { HR for DFS } \\
(95 \% \mathrm{CI})\end{array}$} & \multirow[b]{2}{*}{$\begin{array}{l}\text { mOS (mo) } \\
\text { Low v high }\end{array}$} & \multirow[b]{2}{*}{$\begin{array}{l}\text { HR for OS } \\
(95 \% \mathrm{CI})\end{array}$} \\
\hline & & & & c-Met ${ }^{\text {low }}$ & c-Met ${ }^{\text {high }}$ & & & & \\
\hline $\begin{array}{l}\text { Ide et al., } \\
\text { (2007) } \\
\text { Japan }\end{array}$ & $\begin{array}{l}\text { Anti-Met, } \\
\text { clone B-2, } \\
1: 100 \quad\end{array}$ & 41 & $\begin{array}{l}\text { Negative: cytoplasmic staining }<30 \% \text { of } \\
\text { tumor cells. } \\
\left.\text { Positive (c-Met }{ }^{\text {tigh }}\right): \geq 30 \%\end{array}$ & $24(58.5 \%)$ & $17(41.5 \%)$ & NA & $\begin{array}{l}2.08(0.72-6.05) \\
P=0.047\end{array}$ & NA & NA \\
\hline $\begin{array}{l}\text { Zhu et al., } \\
\text { (2011) } \\
\text { China }\end{array}$ & $\begin{array}{l}\text { Anti-Met, } \\
\text { ab51067, } \\
1: 100\end{array}$ & 71 & $\begin{array}{l}\text { P-score: } \% \text { of positive tumor cells: } \leq 10 \% \\
=1 ; 11-50 \%=2 ; 51-70 \%=3 ; \geq 71 \%=4 . \\
\text { I-score: } 0=\text { none; } 1=\text { weak } ; 2=\text { moderate; } \\
3=\text { strong. } \\
(\text { c-Met }\end{array}$ & $28(39.4 \%)$ & $43(60.6 \%)$ & NA & NA & NA & $\begin{array}{l}2.43(1.24-4.75) \\
P=0.010\end{array}$ \\
\hline $\begin{array}{l}\text { Park et al., } \\
\text { (2012) } \\
\text { Korea }\end{array}$ & $\begin{array}{l}\text { Anti-phospho- } \\
\text { c-Met }\end{array}$ & 88 & $\begin{array}{l}\text { I-score: } 0=\text { none; } 1=\text { weak; } 2=\text { moderate; } \\
3=\text { strong. } \\
\text { (c-Met thigh: } \geq 2 \text { in } \geq 20 \% \text { of positive tumor } \\
\text { cells) }\end{array}$ & $48(55 \%)$ & $40(45 \%)$ & 17.4 8.5 & $\begin{array}{l}1.30(0.78-2.18) \\
P=0.241\end{array}$ & 23.5 v 21.6 & $\begin{array}{l}1.11(0.75-1.65) \\
P=0.599\end{array}$ \\
\hline $\begin{array}{l}\text { Neuzillet et al., } \\
(2015) \\
\text { France }\end{array}$ & $\begin{array}{l}\text { Anti-Met, } \\
\text { SP44 }\end{array}$ & 131 & $\begin{array}{l}\text { Simplified c-Met score. } \\
\text { (c-Met }{ }^{\text {high }}: \geq 20 \% \text { of tumor cells with strong } \\
\text { membrane staining) }\end{array}$ & $95(72.5 \%)$ & $36(27.5 \%)$ & $20 \vee 9.3$ & $\begin{array}{l}2.165(1.40-3.34) \\
P=0.0005\end{array}$ & 35 v 18.2 & $\begin{array}{l}1.83(1.16-2.90) \\
P=0.0098\end{array}$ \\
\hline $\begin{array}{l}\text { Tomihara et al., } \\
\text { (2017) } \\
\text { Japan }\end{array}$ & $\begin{array}{l}\text { Anti-human } \\
\text { c-Met, 1:400 }\end{array}$ & 92 & $\begin{array}{l}\text { Semiquantititave scoring method (P-score } x \\
\text { I-score) }[26] \text {. } \\
\text { (c-Met }{ }^{\text {high }}: \geq 7 \text { points) }\end{array}$ & $43(46.7 \%)$ & $49(53.3 \%)$ & NA & $\begin{array}{l}2.58(1.47-4.63) \\
P=0.001\end{array}$ & NA & $\begin{array}{l}2.95(1.61-5.65) \\
P=0.0004\end{array}$ \\
\hline
\end{tabular}

IHC, immunohistochemistry; P-score, proportion score; I-score, intensity score; mDFS, median disease-free survival; mOS, median overall survival; HR, hazard ratio; CI, confidence interval; NA, not available.

\section{Impact of c-Met expression on disease-free survival}

From four studies [21, 23-25], 250 patients were included in the meta-analysis of HRs for disease-free survival (DFS). Compared with patients with PAC showing low c-Met expression, patients with c-Met-high tumor showed significantly worse DFS (HR $=1.94[95 \%$ CI, 1.46-2.56], $P=0.00001$ ) (Figure 2A). The fixedeffect model was used because there was no significant heterogeneity $\left(X^{2}=3.48, P=0.32, I^{2}=14 \%\right)$.

\section{Impact of c-Met expression on overall survival}

From four studies [22-25], 382 patients were included in the meta-analysis of HRs for OS. Patients with c-Met-high PAC showed significantly shorter OS than those with c-Met-low PAC (HR $=1.86$ [95\% CI, 1.19-2.91], $P=0.006$ ) (Figure 2B). The random-effect model was adopted because of significant heterogeneity across the studies $\left(X^{2}=8.87, P=0.03, I^{2}=66 \%\right)$.

\section{Publication bias}

Visual inspection of the funnel plots for DFS and OS showed symmetry, indicating there were no publication biases (Figure 3A and 3B).

\section{DISCUSSION}

In this meta-analysis, we evaluated the prognostic impact of c-Met overexpression in patients with resected PAC. The results show that high c-Met expression is associated with significantly poor DFS or OS. To our knowledge, this is the first meta-analysis suggesting that
c-Met overexpression represent an adverse prognostic marker in patients with PAC.

PAC shows unfavorable prognosis with the most aggressive tumor biology. The traditional post-operative prognostic factors such as tumor size, lymph node involvement, or status of resection margin are insufficient to predict patients with a high risk of recurrence or metastasis. Therefore, the identification of reliable predictive markers and potential therapeutic targets is essential to guide individual treatment strategies and improve prognosis in patients with PAC. c-Met has been proven to play a critical role in the pathogenesis and progression of many tumor types [9-12].

The enhanced expression of c-Met has also been observed in PAC [19-26]. Because most studies had a small number of patients and adopted various IHC scoring methods, however, they could not draw a consensus regarding the prognostic value of c-Met. In an early study by Furukawa et al., patients with PAC showing diffuse staining for c-Met showed better OS than those with tumors showing no or focal staining $(P=0.026$ by log-rank test). However, this study had a very small sample size (27 patients for OS comparison) and classified patients by the c-Met positivity or negativity, not by the c-Met expression status (low or high). In the current meta-analysis, we only included studies comparing survivals (DFS or OS) according to the c-Met expression status. Patients with c-Met-high PAC showed significantly shorter DFS $(\mathrm{HR}=1.94, P<0.00001)$ and $\mathrm{OS}(\mathrm{HR}=1.86$, $P=0.006)$, compared with those with c-Met-low tumor. Our results indicate that high c-Met expression is a significant prognostic marker for poor survival in patients with resected PAC.

Multiple studies also demonstrated that high expression of c-Met was associated with poor survival in 
various cancers [13-18]. Thus, interference with c-Met activation may provide an effective therapeutic approach for cancers with c-Met overexpression [27]. Several c-Met inhibitors are currently under active investigation in various cancer types [10, 28-31]. The efficacy of c-Met-targeting agents has been associated with high c-Met expression in non-small-cell lung cancer and hepatocellular carcinoma [28, 29]. Therefore, patients with PAC overexpressing c-Met protein might be good candidates for c-Met inhibitors. Indeed, it has been demonstrated that targeting c-Met impairs tumor growth and improves activity of gemcitabine in PAC [29-32].

However, the major challenge for clinical development of c-Met inhibitors is that there are no standardized methods and criteria for c-Met overexpression. A variety of methods such as IHC,

A

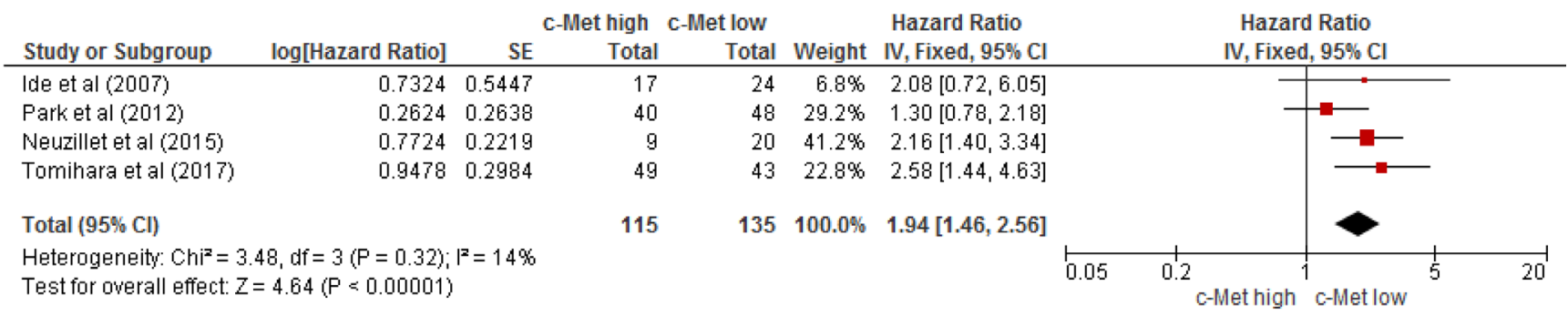

B

\begin{tabular}{|c|c|c|c|c|c|c|c|c|c|c|c|}
\hline Study or Subgroup & log[Hazard Ratio] & SE & $\begin{array}{r}\text { c-Met high } \\
\text { Total } \\
\end{array}$ & $\begin{array}{r}\text { c-Met low } \\
\text { Total } \\
\end{array}$ & Weight & $\begin{array}{c}\text { Hazard Ratio } \\
\text { IV, Random, } 95 \% \mathrm{Cl}\end{array}$ & & $\begin{array}{r}\text { Hazarc } \\
\text { IV, Rando }\end{array}$ & $\begin{array}{l}\text { d Ratio } \\
\mathrm{m}, 95 \% \mathrm{Cl}\end{array}$ & & \\
\hline Zhu et al (2011) & 0.8879 & 0.3433 & 43 & 28 & $20.5 \%$ & $2.43[1.24,4.76]$ & & & & & \\
\hline Neuzillet et al (2015) & 0.6054 & 0.2344 & 36 & 95 & $27.3 \%$ & $1.83[1.16,2.90]$ & & & & & \\
\hline Park et al (2012) & 0.1054 & 0.2003 & 40 & 48 & $29.7 \%$ & $1.11[0.75,1.65]$ & & & & & \\
\hline Tomihara et al (2017) & 1.0825 & 0.3093 & 49 & 43 & $22.5 \%$ & $2.95[1.61,5.41]$ & & & & & \\
\hline Total $(95 \% \mathrm{Cl})$ & & & 168 & 214 & $100.0 \%$ & $1.86[1.19,2.91]$ & & & & & \\
\hline \multicolumn{7}{|c|}{$\begin{array}{l}\text { Heterogeneity: } \text { Tau }^{2}=0.13 ; \mathrm{Chi}^{2}=8.87, \mathrm{df}=3(\mathrm{P}=0.03) ; \mathrm{I}^{2}=66 \% \\
\text { Test for overall effect: } Z=2.74(\mathrm{P}=0.006)\end{array}$} & $\begin{array}{ll}0.1 & 0.2\end{array}$ & $\begin{array}{c}1 \\
0.5 \\
\text { c-Met high }\end{array}$ & $\frac{1}{2}$ & $\frac{1}{5}$ & 10 \\
\hline
\end{tabular}

Figure 2: Forest plots for disease-free survival (A) and overall survival (B).

A

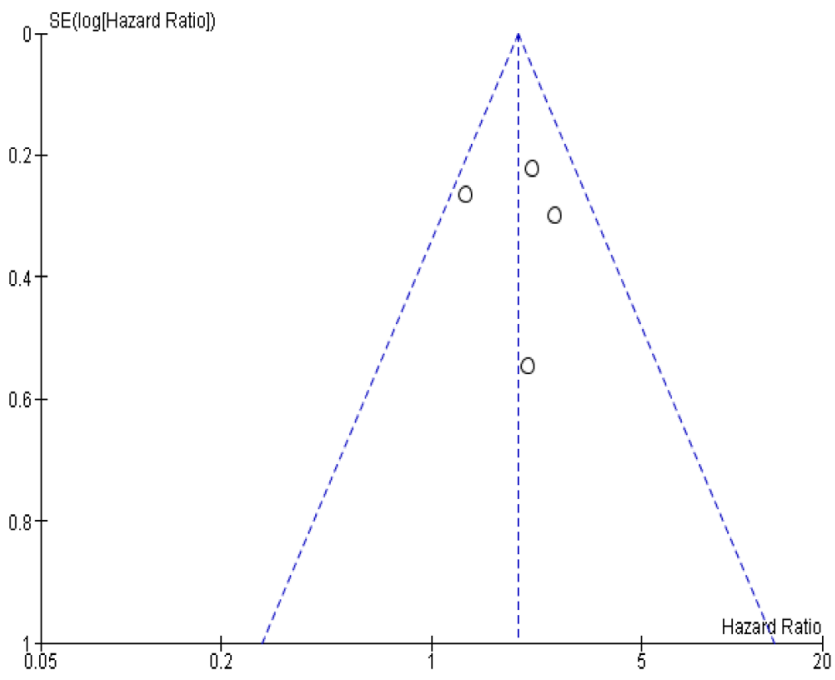

B

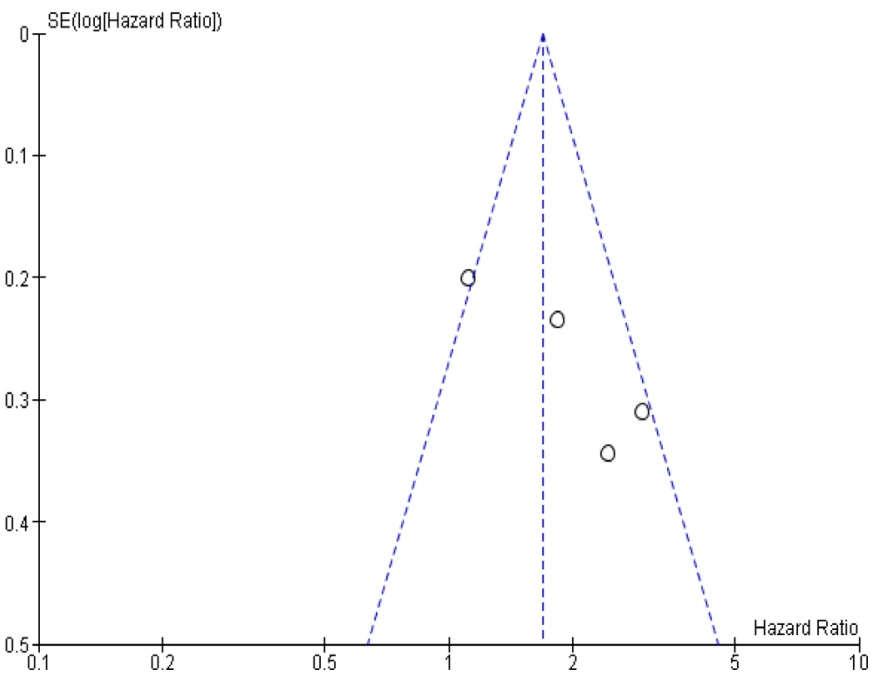

Figure 3: Funnel plots for publication bias regarding disease-free survival (A) and overall survival (B). 
Western blot, fluorescence in situ hybridization, or realtime quantitative PCR are currently used for assessing c-Met status [13]. In this meta-analysis, the included studies adopted the various IHC methods with the different criteria for c-Met overexpression. The discrepancies in the prognostic value of c-Met overexpression in the previous reports with PAC might be attributable to the different c-Met scoring methods. Therefore, the definition of a reliable guideline for c-Met status is an essential prerequisite for assessing the prognostic role of c-Met expression and developing c-Met inhibitors in solid tumors.

Our study has inherent limitations that should be noted. First, the meta-analysis included a small number of studies with a limited sample size. Second, the included studies were all retrospectively performed. Third, of the five studies, four were conducted in Asia. Finally, as we already mentioned, IHC criteria to stratify c-Met status were various among studies.

In conclusion, our meta-analysis demonstrates that c-Met overexpression is a significant prognostic marker for poor survival in patients who underwent surgical resection for PAC. However, larger studies using standardized methods are still needed to verify the prognostic role of c-Met expression in PAC.

\section{MATERIALS AND METHODS}

\section{Publication searching strategy}

This study was conducted according to the Preferred Reporting Items for Systematic Reviews and MetaAnalyses (PRISMA) guidelines [33]. We performed a systematic computerized search of the electronic database PubMed, Embase, and Google Scholar (up to April 2017). The search was carried out using the following keywords: 'c-Met' or 'Met' and 'pancreatic cancer' or 'pancreas neoplasm' or 'pancreatic adenocarcinoma'. The related articles function in the PubMed was also used to identify all relevant articles.

\section{Inclusion criteria}

Eligible studies should meet the following inclusion criteria: (i) patients had a diagnosis of PAC; (ii) DFS and/ or OS were analyzed by c-Met expression status; (iii) HRs with $95 \%$ CIs for DFS or OS were reported or could be calculated from the data provided; (iv) papers were written in English.

\section{Data extraction}

Data extraction was carried out independently by two investigators (BJK and HSK). If these two authors did not agree, other investigators (JHK and HJJ) were consulted to resolve the dispute.
The following data were extracted from all eligible studies: first author's name, year of publication, country, number of patients, tumor stage, treatment, methodology of IHC, the criteria used to dichotomize c-Met expression as 'high' or 'low', and HR with 95\% CIs for DFS or OS.

\section{Statistical analysis}

Statistical values used in this meta-analysis were obtained directly from the original articles. When papers had no HR and 95\% CI, the Engauge Digitizer version 9.1 was used to estimate the needed data from KaplanMeier curves. The effect size of DFS and OS was combined through HR and its 95\% CI. Heterogeneity among studies was estimated using the chi-squarebased Cochran's Q statistic and $I^{2}$ inconsistency test: $P<0.1$ and $I^{2}>50 \%$ indicated the presence of significant heterogeneity. The fixed-effects model (Mantel-Haenszel method) was selected to calculate the pooled HR when substantial heterogeneity was not observed. When significant heterogeneity was detected across studies, we adopted the random-effects model (DerSimonian-Laird method).

The RevMan version 5.2 was used to combine the data. The plots show a summary estimate of the results from all the studies combined. The size of the squares represents the estimate from each study and reflects the statistical 'weight' of the study (relative contribution to the summary estimate). Results are presented as forest plots with diamonds representing estimate of the pooled effect and the width of diamond representing its precision. The line of no effect is number one for binary outcomes, which depicts statistical significance if not crossed by the diamond [34]. All reported $P$-values were two-sided and $P<0.05$ was considered statistically significant. Publication bias was assessed graphically by the funnel plot method [35].

\section{ACKNOWLEDGMENTS AND FUNDING}

This work had no specific funding support.

\section{CONFLICTS OF INTEREST}

All authors have declared no competing interest.

\section{REFERENCES}

1. Ferlay J, Soerjomataram I, Dikshit R, Eser S, Mathers C, Rebelo M, Parkin DM, Forman D, Bray F. Cancer incidence and mortality worldwide: sources, methods and major patterns in GLOBOCAN 2012. Int J Cancer. 2015; 136:359-86.

2. Jung KW, Won YJ, Oh CM, Kong HJ, Lee DH, Lee KH. Community of Population-Based Regional Cancer Registries. Cancer statistics in Korea: incidence, mortality, 
survival, and prevalence in 2014. Cancer Res Treat. 2017; 49:292-305.

3. Siegel RL, Miller KD, Jemal A. Cancer statistics, 2016. CA Cancer J Clin. 2016; 66:7-30.

4. Khan SA, Taylor-Robinson SD, Toledano MB, Beck A, Elliott P, Thomas HC. Changing international trends in mortality rates for liver, biliary and pancreatic tumours. J Hepatol. 2002; 37:806-13.

5. Conroy T, Desseigne F, Ychou M, Bouché O, Guimbaud R, Bécouarn Y, Adenis A, Raoul JL, Gourgou-Bourgade S, de la Fouchardière C, Bennouna J, Bachet JB, KhemissaAkouz F, et al. FOLFIRINOX versus gemcitabine for metastatic pancreatic cancer. N Engl J Med. 2011; 364:1817-25.

6. Von Hoff DD, Ervin T, Arena FP, Chiorean EG, Infante J, Moore M, Seay T, Tjulandin SA, Ma WW, Saleh MN, Harris M, Reni M, Dowden S, et al. Increased survival in pancreatic cancer with nab-paclitaxel plus gemcitabine. N Engl J Med. 2013; 369:1691-703.

7. Ottaiano A, Capozzi M, De Divitiis C, De Stefano A, Botti G, Avallone A, Tafuto S. Gemcitabine mono-therapy versus gemcitabine plus targeted therapy in advanced pancreatic cancer: a meta-analysis of randomized phase III trials. Acta Oncol. 2017; 56:377-83.

8. Avan A, Caretti V, Funel N, Galvani E, Maftouh M, Honeywell RJ, Lagerweij T, Van Tellingen O, Campani D, Fuchs D, Verheul HM, Schuurhuis GJ, Boggi U, et al. Crizotinib inhibits metabolic inactivation of gemcitabine in c-Met-driven pancreatic carcinoma. Cancer Res. 2013; 73:6745-56.

9. Furge KA, Zhang YW, Vande Woude GF. Met receptor tyrosine kinase: enhanced signaling through adapter proteins. Oncogene. 2000; 19:5582-9.

10. Socoteanu MP, Mott F, Alpini G, Frankel AE. c-Met targeted therapy of cholangiocarcinoma. World J Gastroenterol. 2008; 14:2990-4.

11. Blumenschein GR Jr, Mills GB, Gonzalez-Angulo AM. Targeting the hepatocyte growth factor-cMET axis in cancer therapy. J Clin Oncol. 2012; 30:3287-96.

12. Zhang YW, Su Y, Volpert OV, Vande Woude GF. Hepatocyte growth factor/scatter factor mediates angiogenesis through positive VEGF and negative thrombospondin 1 regulation. Proc Natl Acad Sci USA. 2003;100:12718-23.

13. Yan S, Jiao X, Zou H, Li K. Prognostic significance of c-Met in breast cancer: a meta-analysis of 6010 cases. Diagn Pathol. 2015; 10:62.

14. Pyo JS, Kang G, Cho WJ, Choi SB. Clinicopathological significance and concordance analysis of c-MET immunohistochemistry in non-small cell lung cancers: A meta-analysis. Pathol Res Pract. 2016; 212:710-6.

15. Yu S, Yu Y, Zhao N, Cui J, Li W, Liu T. C-Met as a prognostic marker in gastric cancer: a systematic review and meta-analysis. PLoS One. 2013; 8:e79137.
16. Liu Y, Yu XF, Zou J, Luo ZH. Prognostic value of c-Met in colorectal cancer: a meta-analysis. World J Gastroenterol. 2015; 21:3706-10.

17. Peng J, Qi S, Wang P, Li W, Liu C, Li F. Diagnosis and prognostic significance of c-Met in cervical cancer: a metaanalysis. Dis Markers. 2016; 2016:6594016.

18. Kim JH, Kim HS, Kim BJ, Jang HJ, Lee J. Prognostic value of c-Met overexpression in hepatocellular carcinoma: a meta-analysis and review. Oncotarget. 2017. https://doi. org/10.18632/oncotarget.20087. [Epub ahead of print].

19. Furukawa T, Duguid WP, Kobari M, Matsuno S, Tsao MS. Hepatocyte growth factor and Met receptor expression in human pancreatic carcinogenesis. Am J Pathol. 1995; 147:889-95.

20. Gardian K, Janczewska S, Olszewski WL, Durlik M. Analysis of pancreatic cancer microenvironment: role of macrophage infiltrates and growth factors expression. J Cancer. 2012; 3:285-91.

21. Ide T, Kitajima Y, Miyoshi A, Ohtsuka T, Mitsuno M, Ohtaka K, Miyazaki K. The hypoxic environment in tumorstromal cells accelerates pancreatic cancer progression via the activation of paracrine hepatocyte growth factor/c-Met signaling. Ann Surg Oncol. 2007; 14:2600-7.

22. Zhu GH, Huang C, Qiu ZJ, Liu J, Zhang ZH, Zhao N, Feng ZZ, Lv XH. Expression and prognostic significance of CD151, c-Met, and integrin alpha3/alpha6 in pancreatic ductal adenocarcinoma. Dig Dis Sci. 2011; 56:1090-8

23. Park JK, Kim MA, Ryu JK, Yoon YB, Kim SW, Han HS, Kang GH, Kim H, Hwang JH, Kim YT. Postoperative prognostic predictors of pancreatic ductal adenocarcinoma: clinical analysis and immunoprofile on tissue microarrays. Ann Surg Oncol. 2012; 19:2664-72.

24. Neuzillet C, Couvelard A, Tijeras-Raballand A, de Mestier L, de Gramont A, Bédossa P, Paradis V, Sauvanet A, Bachet JB, Ruszniewski P, Raymond E, Hammel P, Cros J. High c-Met expression in stage I-II pancreatic adenocarcinoma: proposal for an immunostaining scoring method and correlation with poor prognosis. Histopathology. 2015; 67:664-76.

25. Tomihara H, Yamada D, Eguchi H, Iwagami Y, Noda T, Asaoka T, Wada H, Kawamoto K, Gotoh K, Takeda Y, Tanemura M, Mori M, Doki Y. MicroRNA-181b-5p, ETS1, and the c-Met pathway exacerbate the prognosis of pancreatic ductal adenocarcinoma after radiation therapy. Cancer Sci. 2017; 108:398-407.

26. Olaussen KA, Dunant A, Fouret P, Brambilla E, André F, Haddad V, Taranchon E, Filipits M, Pirker R, Popper HH, Stahel R, Sabatier L, Pignon JP, et al. DNA repair by ERCC1 in non-small-cell lung cancer and cisplatin-based adjuvant chemotherapy. N Engl J Med. 2006; 355:983-91.

27. Peters S, Adjei AA. MET: a promising anticancer therapeutic target. Nat Rev Clin Oncol. 2012; 9:314-26. 
28. Spigel DR, Ervin TJ, Ramlau RA, Daniel DB, Goldschmidt JH Jr, Blumenschein GR Jr, Krzakowski MJ, Robinet G, Godbert B, Barlesi F, Govindan R, Patel T, Orlov SV, et al. Randomized phase II trial of onartuzumab in combination with erlotinib in patients with advanced non-small-cell lung cancer. J Clin Oncol. 2013; 31:4105-14.

29. Santoro A, Rimassa L, Borbath I, Daniele B, Salvagni S, Van Laethem JL, Van Vlierberghe H, Trojan J, Kolligs FT, Weiss A, Miles S, Gasbarrini A, Lencioni M, et al. Tivantinib for second-line treatment of advanced hepatocellular carcinoma: a randomised, placebo-controlled phase 2 study. Lancet Oncol. 2013; 14:55-63.

30. Brandes F, Schmidt K, Wagner C, Redekopf J, Schlitt HJ, Geissler EK, Lang SA. Targeting cMET with INC280 impairs tumour growth and improves efficacy of gemcitabine in a pancreatic cancer model. BMC Cancer. $2015 ; 15: 71$.

31. Avan A, Quint K, Nicolini F, Funel N, Frampton AE, Maftouh M, Pelliccioni S, Schuurhuis GJ, Peters GJ, Giovannetti E. Enhancement of the antiproliferative activity of gemcitabine by modulation of c-Met pathway in pancreatic cancer. Curr Pharm Des. 2013; 19:940-50.
32. Hage C, Rausch V, Giese N, Giese T, Schönsiegel F, Labsch S, Nwaeburu C, Mattern J, Gladkich J, Herr I. The novel c-Met inhibitor cabozantinib overcomes gemcitabine resistance and stem cell signaling in pancreatic cancer. Cell Death Dis. 2013; 4:e627.

33. Panic N, Leoncini E, de Belvis G, Ricciardi W, Boccia S. Evaluation of the endorsement of the preferred reporting items for systematic reviews and meta-analysis (PRISMA) statement on the quality of published systematic review and meta-analyses. PLoS One. 2013; 8:e83138.

34. Wald NJ, Bestwick JP. Presentation of meta-analysis plots. J Med Screen. 2015; 22:49-51.

35. Sterne JA, Sutton AJ, Ioannidis JP, Terrin N, Jones DR, Lau J, Carpenter J, Rücker G, Harbord RM, Schmid CH, Tetzlaff J, Deeks JJ, Peters J, et al. Recommendations for examining and interpreting funnel plot asymmetry in meta-analyses of randomised controlled trials. BMJ. 2011; 343:d4002. 